\title{
"FRUSTRATION" IN THE COURT OF APPEAL
}

\author{
David McLauchlan*
}

This article discusses the decision of the New Zealand Court of Appeal in Planet Kids Ltd v Auckland Council [2012] NZCA 562, [2013] 1 NZLR 485. The Court upheld the Council's argument that its contract with the appellants had been frustrated, and therefore it was released from the obligation to render the performance it had promised, notwithstanding that it had achieved in substance everything that it set out to achieve at the time of the contract. The author argues that the case was wrongly decided.

\section{INTRODUCTION}

It is well established that a contract may be discharged under the doctrine of frustration where an event occurs after formation of the contract that makes performance illegal or impossible or renders the obligation to perform something radically or fundamentally different from that contemplated by the parties at the time of formation. The doctrine is easy to state in this summary form but its application to the facts of individual cases is often fraught with difficulty. A recent example of this is provided by the decision of the Court of Appeal in Planet Kids Ltd v Auckland Council $^{1}$ where the Court upheld the respondent's argument that the contract in question had been frustrated. The decision is particularly remarkable because, so far as I am aware, there has been no other case where a contracting party achieved in substance everything that it set out to achieve at the time of the contract yet it was successful in persuading the court that the contract had been frustrated, so that it was released from the obligation to render the performance it had promised. This led me to wonder whether the decision could possibly be right and, after further reflection, the answer I came to was no.

\footnotetext{
* Professor of Law, Victoria University of Wellington; Professorial Fellow, The University of Melbourne; Honorary Professor, TC Beirne School of Law, The University of Queensland. I am grateful to Lauren Brazier for her research and other assistance. All errors are of course mine.

1 Planet Kids Ltd v Auckland Council [2012] NZCA 562, [2013] 1 NZLR 485.
} 
The purpose of this article is to explain the reasons for this conclusion. In order to do so, it is first necessary to say a little more about the doctrine of frustration and the legal test for its application.

\section{THE DOCTRINE OF FRUSTRATION}

\section{A A Question of Construction}

It is now axiomatic that the question of whether a contract is frustrated as a result of a supervening event depends on the construction of the contract. In other words, "[t]he question is whether the contract ... is, on its true construction, wide enough to apply to the new situation: if it is not, then it is at an end". ${ }^{2}$ This essentially means that the answer depends on whether the parties can reasonably be taken to have contemplated that the contract would continue to bind in the circumstances that have arisen.

The classical modern exposition of the doctrine is that by Lord Radcliffe in Davis Contractors Ltd $v$ Fareham Urban District Council. ${ }^{3}$ His Lordship said:

... frustration occurs whenever the law recognizes that without default of either party a contractual obligation has become incapable of being performed because the circumstances in which performance is called for would render it a thing radically different from that which was undertaken by the contract. Non haec in foedera veni. It was not this that I promised to do.

This statement was approved by the House of Lords in National Carriers Ltd $v$ Panalpina (Northern) Ltd ${ }^{4}$ and Pioneer Shipping Ltd v BTP Tioxide Ltd (The Nema) (No 2). ${ }^{5}$ In the former Lord Simon of Glaisdale expanded on Lord Radcliffe's explanation in the following equally wellknown passage: 6

Frustration of a contract takes place when there supervenes an event (without default of either party and for which the contract makes no sufficient provision) which so significantly changes the nature (not merely the expense or onerousness) of the outstanding contractual rights and/or obligations from what the parties could reasonably have contemplated at the time of its execution that it would be unjust to hold them to the literal sense of its stipulations in the new circumstances; in such case the law declares both parties to be discharged from further performance.

2 Davis Contractors Ltd v Fareham Urban District Council [1956] AC 696 (HL) at 721 per Lord Reid.

3 Davis Contractors, above n 2, at 729.

$4 \quad$ National Carriers Ltd v Panalpina (Northern) Ltd [1981] AC 675 (HL) at 688 and 717.

$5 \quad$ Pioneer Shipping Ltd v BTP Tioxide Ltd (The Nema) (No 2) [1982] AC 724 (HL) at 751-752. See also Codelfa Construction Pty Ltd v State Rail Authority of NSW (1982) 149 CLR 337 (HCA) at 357.

6 Panalpina, above n 4, at 700. 
It is important to recognise, however, that the question is not simply "whether there has been a radical change in the circumstances but whether there has been a radical change in the 'obligation' or the actual effect of the promises of the parties construed in the light of the new circumstances ". ${ }^{7}$ It must be shown that performance of the obligation has become "fundamentally different in a commercial sense"8 or, as Diplock LJ put it in Hongkong Fir Shipping Co Ltd v Kawasaki Kisen Kaisha Ltd, ${ }^{9}$ that "the occurrence of the event deprive[s] the party who has further undertakings still to perform of substantially the whole benefit which it was the intention of the parties as expressed in the contract that he should obtain as the consideration for performing those undertakings".

\section{B The Demise of the Implied Term Approach?}

In the early years of its development the application of the doctrine of frustration was seen as depending on whether the contract implicitly provided that it should cease to bind on the occurrence of the supervening event. This implied term "theory" still has its adherents, ${ }^{10}$ but it was criticised in Davis Contractors and finally rejected in Panalpina. Nevertheless, it is worth noting that in the latter case Lord Wilberforce said that the various theories that have been expressed concerning the justification for the doctrine of frustration "shade into one another and that a choice between them is a choice of what is most appropriate to the particular contract under consideration". ${ }^{11}$ His Lordship was even prepared to acknowledge that "it could provisionally be said to be appropriate to refer to an implied term" in the contract in question in that case. ${ }^{12}$ Furthermore, according to Lord Hoffmann, delivering the advice of the Privy Council in Attorney-General of Belize v Belize Telecom Ltd, ${ }^{13}$ implication of terms is an exercise in construction. Implication, his Lordship said, is part of the process of determining the objective meaning of the relevant instrument, "the meaning

7 HG Beale (ed) Chitty on Contracts (31st ed, Sweet and Maxwell, London, 2012) vol 1 at [23.014].

8 Tsakiroglou \& Co Ltd v Noblee Thorl GmbH [1962] AC 93 (HL) at 119 per Lord Reid. See also Panalpina, above $\mathrm{n}$, at 717 per Lord Roskill:

There must have been by reason of some supervening event some such fundamental change of circumstances as to enable the court to say: "this was not the bargain which these parties made and their bargain must be treated as at an end".

9 Hongkong Fir Shipping Co Ltd v Kawasaki Kisen Kaisha Ltd [1962] 2 QB 26 (CA) at 66.

10 Thus, Stephen Smith Contract Theory (OUP, Oxford, 2004) argues (at 374) that "implied term explanations of this area of law ... are more persuasive than the alternatives". See also Brian Langille and Arthur Ripstein "Strictly Speaking - It Went without Saying" (1996) 2 Legal Theory 63, but compare Andrew Robertson "The Limits of Voluntariness in Contract" (2005) 29 MULR 179 at 211-216.

11 Panalpina, above n 4, at 693. This view was endorsed by Brennan $\mathrm{J}$ in Codelfa Construction, above $\mathrm{n} 5$, at 409.

12 At 693

13 Attorney-General of Belize v Belize Telecom Ltd [2009] UKPC 10, [2009] 1 WLR 1988. See generally John McCaughran "Implied Terms: The Journey of the Man on the Clapham Omnibus" (2011) 70 CLJ 607. 
which the instrument would convey to a reasonable person having all the background knowledge which would reasonably be available to the audience to whom the instrument is addressed" (in the case of a contract, the parties thereto). ${ }^{14}$ On this view, implication entails essentially the same exercise as the modern construction approach to questions of frustration; in broad terms, what can the parties reasonably be taken to have intended in the event that has occurred?

\section{Frustration not Lightly to be Found}

In the Davis Contractors case Lord Reid said that "[f]rustration is not to be lightly invoked as the dissolvent of a contract". ${ }^{15}$ This view has been expressed on numerous other occasions, ${ }^{16}$ but most forcefully by Bingham LJ in J Lauritzen AS $v$ Wijsmuller BV (The Super Servant Two $)^{17}$ where he said that "[s]ince the effect of frustration is to kill the contract and discharge the parties from further liability under it, the doctrine is not to be lightly invoked, must be kept within very narrow limits and ought not to be extended".

\section{A Multi-factorial Approach?}

In the course of his illuminating judgment in Edwinton Commercial Corp v Tsavliris Russ (Worldwide Salvage \& Towage) Ltd (The Sea Angel), ${ }^{18}$ which contains the most authoritative discussion of the doctrine of frustration in recent times, Rix LJ argued that, instead of there being a single formula or test to be applied in all cases of alleged frustration, "the application of the doctrine ... requires a multi-factorial approach". His Lordship continued:

14 At [16]. See further $\mathrm{n} 30$ below. Lord Hoffmann's approach has been widely accepted, including by the New Zealand Supreme Court in Dysart Timbers Ltd v Nielsen [2009] NZSC 43, [2009] 3 NZLR 160 at [25] and [62]. However, it has been criticised, in my view unconvincingly, by some academic commentators. It was also rejected by the Singapore Court of Appeal in Foo Jong Peng v Phua Kiah Mai [2012] SGCA 55, [2012] 4 SLR 1267. It is important to understand that when Lord Hoffmann said that implication is part of the process of determining the objective meaning of the relevant instrument he was not referring solely to linguistic meaning of the express terms. He was suggesting that the issue in every case of an alleged implied term is whether, as a matter of construction, the parties can reasonably be taken to have intended their relationship to include the alleged right, obligation, or condition, as the case may be.

15 Davis Contractors, above n 2, at 727. In the same case Viscount Simonds said (at 715) that "the doctrine has been, and must be, kept within very narrow limits".

16 See for example Pioneer Shipping Ltd, above n 5, at 752 and Edwinton Commercial Corp v Tsavliris Russ (Worldwide Salvage \& Towage) Ltd (The Sea Angel) [2007] EWCA Civ 547, [2007] 1 CLC 876 at [111].

17 J Lauritzen AS v Wijsmuller BV (The Super Servant Two) [1990] 1 Lloyd's Rep 1 (CA) at 8.

18 Edwinton Commercial Corp v Tsavliris Russ (Worldwide Salvage \& Towage) Ltd (The Sea Angel) [2007] EWCA Civ 547, [2007] 1 CLC 876 at [111], followed in for example Bunge SA v Kyla Shipping Co Ltd [2012] EWHC 3522 (Comm) at [39]-[42] and ACG Acquisition XX LLC v Olympic Airlines [2012] EWHC 1070 (Comm) at [178]-[185]. 
Among the factors which have to be considered are the terms of the contract itself, its matrix or context, the parties' knowledge, expectations, assumptions and contemplations, in particular as to risk, as at the time of contract, at any rate so far as these can be ascribed mutually and objectively, and then the nature of the supervening event, and the parties' reasonable and objectively ascertainable calculations as to the possibilities of future performance in the new circumstances. Since the subject matter of the doctrine of frustration is contract, and contracts are about the allocation of risk, and since the allocation and assumption of risk is not simply a matter of express or implied provision but may also depend on less easily defined matters such as "the contemplation of the parties", the application of the doctrine can often be a difficult one. In such circumstances, the test of "radically different" is important: it tells us that the doctrine is not to be lightly invoked; that mere incidence of expense or delay or onerousness is not sufficient; and that there has to be as it were a break in identity between the contract as provided for and contemplated and its performance in the new circumstances.

An important theme of the judgment is that to isolate a single factor from the other facts and circumstances of the case is to adopt "too blunt an instrument". ${ }^{19}$ For example, in relation to foreseeability of the risk, a factor that often features in the frustration cases, his Lordship said: ${ }^{20}$

\footnotetext{
In a sense, most events are to a greater or lesser degree foreseeable. That does not mean that they cannot lead to frustration. Even events which are not merely foreseen but made the subject of express contractual provision may lead to frustration: as occurs when an event such as a strike, or a restraint of princes, lasts for so long as to go beyond the risk assumed under the contract and to render performance radically different from that contracted for. However ... the less that an event, in its type and its impact, is foreseeable, the more likely it is to be a factor which, depending on other factors in the case, may lead on to frustration.
}

Resolution of frustration cases therefore requires an exercise of judgment as to whether, in the light of all the circumstances, it is just to allocate the risk of the supervening event to one party or the other. In the words of Rix LJ, the court, "putting itself in the position of the parties, and viewing the matter in the role of reasonable and well-informed men", must make an overall assessment of whether "those parties would or properly speaking should have formed the view that, in all fairness and consistently with the demands of justice, their contract, as something whose performance in the new circumstances ... had become 'radically different', had ceased to bind". ${ }^{21}$

\section{E The Demands of Justice}

It would be universally accepted that the court does not have "a broad absolving power to set aside a contract whenever a change of circumstances causes hardship to one of the contracting

19 At [118].

20 At [127].

21 At [120]. 
parties". ${ }^{22}$ Nevertheless, as Bingham LJ stated in J Lauritzen AS $v$ Wijsmuller BV (The Super Servant Two), it is "not open to question" that: ${ }^{23}$

[t]he doctrine of frustration was evolved to mitigate the rigour of the common law's insistence on literal performance of absolute promises ... The object of the doctrine was to give effect to the demands of justice, to achieve a just and reasonable result, to do what is reasonable and fair, as an expedient to escape from injustice where such would result from enforcement of a contract in its literal terms after a significant change in circumstances ...

This view was discussed at some length by Rix LJ in The Sea Angel. ${ }^{24}$ His Lordship referred to "the role that the concept of justice plays in the doctrine" as having "a distinguished pedigree",25 quoting, inter alia, the view of Lord Simon in Panalpina ${ }^{26}$ that:

... in the words of Lord Wright in the Cricklehood Property case [Cricklewood Property and Investment Trust Ltd v. Leighton's Investment Trust Ltd [1945] AC 221] at $\mathrm{p} 241$ : "... the doctrine of frustration is modern and flexible and is not subject to being constricted by an arbitrary formula." It is therefore on the face of it apt to vindicate justice wherever owing to relevant supervening circumstances the enforcement of any contractual arrangement in its literal terms would produce injustice.

Then, after explaining his "multi-factorial" approach, the judge said: ${ }^{27}$

What the "radically different" test ... does not in itself tell us is that the doctrine is one of justice, as has been repeatedly affirmed on the highest authority. Ultimately the application of the test cannot safely be performed without the consequences of the decision, one way or the other, being measured against the demands of justice. Part of that calculation is the consideration that the frustration of a contract may well mean that the contractual allocation of risk is reversed. A time charter is a good example. Under such a charter, the risk of delay, subject to express provision for the cessation of hire under an off-hire clause, is absolutely on the charterer. If, however, a charter is frustrated by delay, then the risk of delay is wholly reversed: the delay now falls on the owner. If the provisions of a contract in their literal sense are to make way for the absolving effect of frustration, then that must, in my judgment, be in the interests of justice and not against those interests. Since the purpose of the doctrine is to do justice, then its

22 Chitty, above n 7, at [23.008]. In Panalpina, above n 4, at 712 Lord Roskill said: "The doctrine is no arbitrary dispensing power to be exercised at the subjective whim of the judge by whom the issue has to be determined."

23 The Super Servant Two, above n 17, at 8.

24 The Sea Angel, above n 18.

25 At [86].

26 Panalpina, above $\mathrm{n}$ 4, at 701.

27 At [112]. 
application cannot be divorced from considerations of justice. Those considerations are among the most important of the factors which a tribunal has to bear in mind.

His Lordship was prepared to accept that the court has no "broad absolving power" to grant relief from hardship and that considerations of justice do not supersede the rules governing the operation of the doctrine of frustration, but only: 28

as long as it is not sought to apply those rules as though they are expected to lead one automatically, and without an exercise of judgment, to a determined answer without consideration of the demands of justice.

Such considerations are "not an additional test" but rather "a relevant factor which underlies all and provides the ultimate rationale of the doctrine". ${ }^{29}$ Further, if this factor is used "as a reality check, its answer should conform with a proper assessment of the issue of frustration" and "[i]f it does not appear to do so, it is probably a good indication of the need to think again." 30

28 At [113].

29 At [132].

30 At [132]. Although the judgment is not referred to, Rix LJ's multi-factorial approach to construction and his emphasis on the need to consider the demands of justice finds support in Professor John Carter's recent work on commercial construction: see J W Carter The Construction of Commercial Contracts (Hart Publishing, Oxford, 2013). In the course of discussing (at [2.34]) "a 'factorial' or circumstantial approach to construction", the author points out that the application of Lord Radcliffe's test in Davis Contractors "is a matter of commercial construction" and that in this context "a commercial judgment as to what is 'fair and reasonable' - based on factual considerations - is extremely important."

It is perhaps worth recalling also that, immediately before propounding his well-known test, Lord Radcliffe said that, even on an implied term approach, the inquiry must be as to the parties' objective intention - what they, "as fair and reasonable men, would presumably have agreed upon" - and he then famously observed (above $\mathrm{n} 2$, at 728):

By this time it might seem that the parties themselves have become so far disembodied spirits that their actual persons should be allowed to rest in peace. In their place there rises the figure of the fair and reasonable man. And the spokesman of the fair and reasonable man, who represents after all no more than the anthropomorphic conception of justice, is and must be the court itself.

See further Lord Hoffmann's interesting extra-judicial remarks in "Anthropomorphic Justice: The Reasonable Man and His Friends" (1995) 29 The Law Teacher 127 at 140. He suggests that the passages in Lord Radcliffe's judgment referred to above show that "implied terms are a question of construction just like any other question of construction, that one is looking for what the text means according to the normal rules and techniques of construction", and continues:

[Lord Radcliffe's] contribution was to say: instead of asking, as earlier decisions had suggested, whether we should imply a term that in the events which have happened the contract should cease to bind, let us rather ask whether as a matter of construction the contract has ceased to bind. Can the party claiming frustration say as a matter of construction: non haec in foedera veni it was not this that I promised to do? But that does not mean that the judges who adopted the implied term theory of frustration were wrong. They were also right because the implication of any implied term in fact 


\section{THE PLANET KIDS CASE}

We are now in a position to discuss the Court of Appeal's decision in Planet Kids Ltd v Auckland Council, ${ }^{31}$ a case where the outcome might have been different if Rix LJ's "reality check" had been applied.

\section{A The Facts}

Planet Kids ran a childcare business in premises leased from the Auckland Council. In early 2010 the Council required the land in order to complete a roading project. That project necessitated demolition of the building that Planet Kids occupied. Since earlier negotiations had failed to produce an agreement, the Council initiated the process for compulsorily acquiring the leasehold interest under the Public Works Act 1981. Planet Kids responded by lodging an objection with the Environment Court and this led to further negotiations that culminated in the parties executing a settlement agreement in June 2010. The agreement provided for payment by the Council of over $\$ 550,000$ in full and final settlement of Planet Kids' claim for compensation under the Act. The Council was to pay a deposit of 10 per cent, which was duly paid. The agreement also resolved a rental dispute. This involved the Council forgiving some $\$ 40,000$ by way of unpaid rental. Settlement was to take place on 20 December 2010, or earlier if agreed, at which time Planet Kids would hand over a surrender of the lease and a restraint of trade covenant preventing the operation of a childcare business within a $1 \mathrm{~km}$ area for one year, the latter being a formality required by the Act where compensation was being paid for the loss of goodwill of a business.

Other material terms of the agreement provided that the business remained at Planet Kids' sole risk pending settlement and that the Council was entitled to enter the land for the purpose of conducting preliminary work in relation to the roading project. The latter provision enabled the Council to move swiftly with the call for tenders and the contract was awarded on 1 October. By coincidence, the very next day a fire destroyed the building which Planet Kids occupied. The fire was deliberately lit but the arsonist was never apprehended.

The Council, no doubt acting on legal advice, took the view that the occurrence of this event meant that it was no longer bound by the settlement agreement. Under $\mathrm{cl} 40$ of the lease Planet Kids' leasehold interest was immediately terminated if the premises were destroyed by fire. Therefore there was no longer any lease in existence to surrender on settlement. The settlement agreement had been frustrated. Planet Kids were not entitled to recover the balance of the agreed compensation. Furthermore, they had to refund the deposit and pay the $\$ 40,000$ in outstanding rent that had been

is also a question of construction ... [O]ne asks: is this implication necessary to make sense of the agreement?

31 Planet Kids Ltd v Auckland Council, above $\mathrm{n} 1$. 
forgiven. Not surprisingly, Planet Kids denied that the contract had been frustrated and sued to recover the balance of the compensation.

\section{B The High Court's Decision}

In the High Court ${ }^{32}$ Peters $\mathrm{J}$ accepted the Council's argument. The termination of the lease brought about by the fire destroyed the parties' basic assumption at the time of the settlement agreement that Planet Kids would have an interest in the land to surrender at the settlement date. The agreement was frustrated and therefore both parties were discharged from further performance.

\section{The Court of Appeal's Decision and Reasoning}

Planet Kids' appeal was dismissed by the Court in a judgment delivered by Ellen France J. ${ }^{33}$ After outlining counsel's arguments and some of the authorities explaining the doctrine of frustration, the Court noted "two possible ways of construing the settlement agreement". ${ }^{34}$ First, it was simply a means of obtaining surrender of the lease and resuming possession and use of the land. On this analysis, the contract was not frustrated. It was "immaterial that there was no lease to surrender because the intention was to remove the business and that goal [had] been achieved". ${ }^{35}$ The Council would suffer no hardship in paying for the agreed compensation because it had "achieved its objective". Furthermore, it had "obtained the benefit of certainty" and "resolved other matters in issue between the parties, particularly, the dispute over rental". ${ }^{36}$

The alternative analysis was to view the agreement as "the contractual means of implementing the Council's powers under the Public Works Act". ${ }^{37}$ On this analysis, the contract was frustrated because "the intention [was] to obtain the surrender of the leasehold interest to enable the works to continue". ${ }^{38}$ As Peters J had ruled, Planet Kids no longer held a leasehold interest and accordingly the agreement was "wholly or radically different from that which the parties had agreed". 39

The Court preferred this alternative analysis. Although "[t]he contract had a dual function in the sense that it both fixed compensation for the compulsory acquisition and resolved the rental dispute" it was "clear that the parties entered into it essentially as a means of resolving the dispute between

32 Planet Kids Ltd v Auckland Council HC Auckland CIV-2011-404-1741, 16 December 2011.

33 The other members of the Court were O'Regan P and Arnold J.

34 At [51].

35 At [53].

36 At [53].

37 At [54].

38 At [54].

39 At [54]. 
them which arose as a result of the Council's exercise of its statutory powers under the Public Works Act." ${ }^{40}$ It was "the resultant need to have Planet Kids surrender its leasehold interest that drove the agreement" and therefore the present case did not "invoke the concern frequently underlying the limitation of the doctrine of frustration, namely, that a party should not by this means avoid an agreement which is now just a bad bargain." 41

The latter observation is puzzling. It seems to beg the question. Of course, the contract was not a bad bargain assuming the doctrine of frustration did apply. But, if that assumption is not made, on the surface it was a bad bargain. The Council had agreed to pay substantial compensation in return for Planet Kids' promise to surrender the lease when, if it had put its plans on hold for some months, it would likely have been able to resume occupation of the land without having to pay a single cent.

It was also thought to be significant that not only was the contract entered into by the Council in the exercise of its powers under the Public Works Act but also the statutory process and the Council's powers were reflected in the drafting of the terms of the settlement agreement. ${ }^{42}$ In other words, the Council was "acting primarily as regulator rather than a landlord". ${ }^{43}$ It is difficult to see the relevance of this. There was no question that the Council was acting within its statutory powers and in accordance with the process laid down so that the enforceabilty of the transaction was governed by the general law of contract. Thus, the Council would have had no defence to an action on the contract if there had been no fire but the land was no longer required for the road works due to, say, a change in spending priorities. A prima facie binding contract had been formed that, but for the fire, either party could have enforced in the ordinary way. Thus, if Planet Kids had changed their mind the day after the contract was executed, the Council would have had little difficulty in obtaining a decree of specific performance. The only issue in the case was whether the Council could resist Planet Kids' claim by invoking the doctrine of frustration, a doctrine that does not distinguish between the capacity of the promisor or the authority under which it was acting.

Moreover, and curiously, the Court went on to say: ${ }^{44}$

Another way of testing our approach is to ask whether the position would be the same if the Council was an ordinary landowner, that is, to assume that the regulatory overlay was missing. There is an artificiality in this exercise because, on our approach, the various powers, obligations and rights under the Public Works Act are important. There is a further level of artificiality in this alternative hypothesis

\footnotetext{
40 At [55].

41 At [55].

42 At [56]-[61].

43 At [62].

44 At [62] (emphasis added).
} 
because these issues are normally dealt with by insurance clauses. ${ }^{45}$ Putting those caveats to one side, it seems to us that the analysis would be the same. The Council in this hypothetical scenario would be buying the leasehold interest and the building. With the burning of the building, there would be no leasehold interest and so nothing for the Council to buy.

The hypothetical proves too much. Despite the earlier reasoning that the statutory context was important, we are here told that the answer would be the same in this case if the lessor was an ordinary landowner, presumably one who was anxious to buy out the lease to enable a development of the site to proceed. The hypothetical simply raises, albeit perhaps more starkly, the very issue in the case. And, assuming that the building was to be demolished by the landowner in any event and that the risk of the supervening event that extinguished the lease was not allocated by the terms of the settlement agreement, it seems counter-intuitive to hold that the agreement was frustrated when the landowner achieved its principal purpose and derived other ancillary benefits. This seems to be the kind of literal, technical and inflexible approach to the doctrine that the courts have counselled against.

The Court did go on to acknowledge that there was "force" in Planet Kids' arguments that there was more to the agreement than the surrender of the lease (although the other matters dealt with, including the settlement of the rental dispute, were later described as "peripheral"46) and that there was "no hardship in requiring the Council to pay". ${ }^{47}$ Indeed, it said, "any hardship arguably falls on Planet Kids because Planet Kids has partially performed the contract, for instance by allowing the Council access to the premises". ${ }^{48}$ Nevertheless, it was concluded that "when the supervening event makes the contract so radically different from that to which the parties have agreed, that comprises hardship in terms of the doctrine of frustration". 49

The Court also said that "[a] further response to Planet Kids' submission about part performance is that the Frustrated Contracts Act 1944 expressly contemplates that there may have been part performance of a frustrated contract" ${ }^{50}$ It is true that the Act does provide for restitution in respect of sums paid and valuable benefits conferred prior to the frustrating event, ${ }^{51}$ but the problem with

45 The Court referred (at $\mathrm{n}$ 44) to the evidence that "Planet Kids had business interruption insurance but the insurance company was taking the position that the Council was not entitled to terminate the contract, that they had agreed to end the business on 20 December 2010, and that no business interruption insurance monies are payable for losses beyond that date."

46 At [65].

47 At [63].

48 At [63].

49 At [63].

50 At [64].

51 Frustrated Contracts Act 1944, s 3. 
this "response" is that the Act says nothing about the circumstances in which a contract will be held to be frustrated in the first place. Section 3(1) begins with the words:

Where a contract governed by the law of New Zealand has become impossible of performance or been otherwise frustrated, and the parties thereto have for that reason been discharged from the further performance of the contract ....

Thus, the Act assumes that there has first been frustration at common law and, if there has been, it then governs what happens after the event, including empowering the court to make discretionary adjustments to the statutory default rules.

The final substantive point made by the Court was that, as the Council had submitted, the doctrine of frustration applied even though the risk of a fire was foreseeable: ${ }^{52}$

The doctrine is applicable to foreseeable events so long as the party asserting frustration did not assume the risk of the supervening event occurring. Here, the agreement provided that any risks involving Planet Kids' business remained with Planet Kids prior to the settlement date.

Surprisingly, there was no elaboration of the second sentence. It might be read as suggesting that the agreement allocated the risk of fire terminating the lease before settlement to Planet Kids. If this was the Court's view, the point deserved much greater prominence because it would have been a complete answer to Planet Kids' claim. When read in the light of the terms of the lease, it would have been tantamount to an agreement that the settlement agreement came to an end if the risk materialised. It is more likely, however, that the Court, without fully thinking through the ramifications of the point, was simply saying that there was no question of the Council assuming the risk of the supervening event in this case. Rather, any risks relating to the business remained with Planet Kids. The true position is that the clause in question ( $\mathrm{cl} \mathrm{8)}$ was a standard form provision designed, probably ex abundanti cautela, to make it clear that the Council, which was in effect buying out the business, ${ }^{53}$ was not responsible for mishaps or losses that Planet Kids might suffer pending settlement. Significantly, the clause was immediately followed in the contract by a provision ( $\mathrm{cl} \mathrm{9)}$ stating that the Council was not actually buying the business "but merely compensating the lessee for the closure of the business on the same basis as if the business had been sold as a going concern" and that, "for the avoidance of doubt", the lessee remained liable to meet all obligations of the business. It is difficult to accept that $\mathrm{cl} 8$ was drafted with $\mathrm{cl} 40$ of the lease in mind and therefore in effect meant "the Council doesn't have to pay the agreed compensation if an event occurs that terminates the lease before settlement".

52 At [66].

53 Clause 3 of the contract's preamble to the agreement stated that the Council had agreed "to compensate the Lessee for the loss of goodwill arising from a closure of the Lessee's Business, calculated on the same basis as if the Lessee had sold the Lessee's Business to the Council as going concern". 
The Court concluded its judgment by observing that this was "not an easy case" and conceding that "the outcome may well appear a harsh one". ${ }^{54}$ Nevertheless, it felt that this harshness was diminished by the fact that Planet Kids were "not left without a remedy".55 They could seek recovery in respect of benefits conferred on the Council prior to the frustrating event under s 3(3) of the Frustrated Contracts Act. ${ }^{56}$ It seems that the Court principally had in mind the benefit to the Council in obtaining early access to the land. However, this remedy was undoubtedly of little consolation to Planet Kids. The value of the benefit would be difficult to assess and likely to lead to recovery of an inconsequential sum compared to the compensation payable under the agreement. ${ }^{57}$

\section{A FRUSTRATED CONTRACT?}

Despite the unconvincing aspects of its reasoning noted above, it is likely that the Court of Appeal's ultimate decision in Planet Kids will be regarded by some observers as a perfectly unexceptionable application of the doctrine of frustration. After all, they may argue, the main purpose of the settlement agreement was to compensate the appellants for the loss of goodwill that would be caused by the compulsory acquisition of their leased business premises when completion took place, but that goodwill would have been lost anyway as a result of the fire. The only hardship to the appellants stemmed from their failure to obtain adequate contractual protection, both in the lease and the settlement agreement itself, and perhaps their insurance policy. One might respond that it cannot be said for certain that the fire would have occurred and hence the goodwill inevitably lost: for all we know, the arsonist was aware of, and even influenced by, the fact the building was about to be vacated and demolished! ${ }^{58}$ Nevertheless, the fact remains that the fire did occur and that the effect of cl 40 was to bring the lease to an end so that the appellants no longer had a leasehold interest to surrender on completion. Accordingly, the effect of the fire was, as Peters $\mathbf{J}$ found, to destroy a fundamental assumption upon which the settlement arrangement was entered into.

In my view, however, this line of reasoning involves too literalistic an approach to the doctrine of frustration. It represents the "single-factored" approach rejected by Rix LJ in The Sea Angel and pays insufficient regard to the considerations of justice that his Lordship said provide "the ultimate

54 At [67].

55 At [67]

56 At [68].

57 The Court also noted (at [69]) that the Council had indicated a willingness to forgo its claim to the past rent provided the deposit was repaid and suggested that "[t]hat approach, if maintained, would deal with one of the implications of this decision for Planet Kids".

58 This is plausible because Planet Kids had notified their clients that the business was being wound up and that they would have to make alternative child care arrangements for the following year. Also the tender process, and perhaps even that the contract had been awarded, would have been a matter of public knowledge. 
rationale of the doctrine". ${ }^{59}$ If we undertake the judge's "reality check", it reveals that (a) the deal was essentially "done" when the specifically enforceable agreement was signed in June, thus enabling the Council to proceed immediately with its tendering process (which it was particularly anxious to do); (b) the executed surrender of the lease on completion was a pure formality: it was not even required for registration purposes since the lease was unregistered; ${ }^{60}$ and (c) far from the contract turning out to be less advantageous than expected at the time of formation, ${ }^{61}$ in substance the Council achieved everything that it bargained for and as a result it would suffer no hardship if required to complete its obligations: indeed, it might have been better off after the fire through savings on demolition costs and an insurance payout. ${ }^{62}$ With regard to the latter factor, it is clear that, while substantial hardship to the promisor is not sufficient for a finding of frustration, it is necessary. Thus, as Lord Radcliffe said in Davis Contractors: ${ }^{63}$

... it is not hardship or inconvenience or material loss itself which calls the principle of frustration into

play. There must be as well such a change in the significance of the obligation that the thing undertaken

would, if performed, be a different thing from that contracted for.

It can therefore be argued that Planet Kids was not truly a frustration case at all. The Council did not suffer hardship and neither did the supervening event bring about a radical change in the obligation it had assumed. On this view the real issue in the case was whether the contract contained an implied term that the Council's obligation to pay was dependent on the continued existence of the leasehold interest at the settlement date. (Indeed, as discussed earlier, ${ }^{64}$ there is authority for the

59 At [132].

60 In any event, might not the Council, assuming that it had been willing to honour the agreement, still have sensibly insisted on the handing over of an executed surrender on settlement in order to complete its paperwork or, perhaps, put beyond doubt that the lease had indeed been validly extinguished. What if, say, there was a lingering suspicion that the Council bore some responsibility for the circumstances that enabled the arsonist to enter the premises and, as a result, this was seen as calling into question its entitlement to invoke $\mathrm{cl} 40$. The fact that it was common ground in the actual proceedings that the fire had terminated the lease does not undermine any merit this point might have.

61 The question whether the Council would suffer substantial hardship is to be judged in the light of what it sought to achieve at the time the contract was entered into, not in the light of what, with the benefit of hindsight, it might have done to secure the same advantages.

62 The Court of Appeal said (at [63]) that "[t]he Council has received from its insurers over $\$ 36,500$ for loss of rent and a little over $\$ 51,200$ that has been applied to decontamination of asbestos on the premises". Presumably, some or all of the latter expenditure would have been the Council's responsibility if the fire had not occurred.

63 Davis Contractors, above n 2, at 729 (emphasis added). See also The Power Co Ltd v Gore District Council [1997] 1 NZLR 537 (CA) at 553 ("A recurring theme in the various cases is that it is not sufficient that the contract has become more burdensome or performance more expensive. The test is a much higher one.").

64 See text following n 10 above. 
view that an implied term analysis is permissible when it is "most appropriate to the particular contract under consideration"65 even if the case is viewed as one of frustration.)

The question thus arises as to whether an implied term approach would justify the decision in Planet Kids. It is difficult to see how it would. This is so whether one applies the broad modern approach - under which the essential question is whether, in the light of, inter alia, the commercial purpose of the contract, ${ }^{66}$ an implication is necessary "to give effect to the reasonable expectations of the parties"67 - or the traditional "business efficacy" and "officious bystander" or "obviousness" tests. Under the latter, the court would have to decide whether the changed circumstances were "such that, had [the parties] thought of them, they would have taken their chance of them, or such that as sensible men they would have said 'if that happens, of course, it is all over between us"'. ${ }^{68}$ And, in my view, it is implausible to suggest that "sensible men" would give an affirmative answer if the objective bystander butted in the instant before the contract was formed and asked "since the lease comes to an end in the event of fire destroying the premises, will your settlement agreement cease to be binding on the Council if there is a fire before completion is due?" Would not a fair and reasonable person in the position of Planet Kids respond "we need finality and are not prepared to accept that risk"? And would not a fair and reasonable Council who had a similar desire for finality be unlikely to insist on termination because destruction of the premises was not inimical to its purpose ${ }^{69}$

Finally, there is a wider policy aspect to the case that impacts on the justice of allowing the Council to escape its contractual obligations. It concerns the nature of the agreement entered into. It was a settlement or compromise agreement that was intended to achieve finality. The appellants gave up their right to contest the Council's compulsory acquisition of their leasehold interest and agreed to relinquish that interest in return for the compensation and other entitlements specified in

65 Panalpina, above $\mathrm{n}$ 4, at 693 per Lord Wilberforce.

66 See G McMeel The Construction of Contracts (2nd ed, OUP, Oxford, 2011) at [11.09].

67 Equitable Life Assurance Society v Hyman [2002] 1 AC 408 (HL) at 459. See also Belize Telecom, above n 13 , at [23].

68 FA Tamplin Steamship Co Ltd v Anglo Mexican Petroleum Products Co Ltd [1916] 2 AC 397 (HL) at 404 per Lord Loreburn.

69 Immediately after the passage from his "Anthropomorphic Justice" article quoted above n 30, Lord Hoffmann said:

The officious bystander test is useful in reminding us that before we decide that the text contains by implication an obligation which is not expressly stated, we need to be fairly confident that it would not otherwise make sense. But the same is true when we give the words a secondary meaning and no one thinks that this is anything other than a matter of objective construction. By conjuring up the image of the actual parties in such vivid reality, the officious bystander distracts the court from the objectivity with which it should interpret the text. 
the settlement agreement. Thus, each party secured certainty. The appellants obtained a promise of reasonable compensation for the loss of their business and were able to commence winding it up in an orderly fashion and planning for the future. The Council obtained a specifically enforceable agreement enabling it to proceed immediately, not just after completion, with its roading project, and it did so. In such circumstances, "the law favours upholding compromises". ${ }^{70}$ Normally there would have to be a compelling legal reason, such as common fundamental mistake, fraud or misrepresentation, before a court would entertain setting aside such an agreement. In Planet Kids, by contrast, the Council was able to escape its obligations by invoking what can only be described as a pure technicality in circumstances where for all practical purposes it had achieved everything it set out to achieve.

70 Kyle Bay Ltd v Underwriters Subscribing Under Policy No 019057/08/01 [2006] EWHC 607 (Comm) at [58]. See also for example Colchester BC v Smith [1992] Ch 421 (CA) at 435 ("the courts have an interest in upholding agreements to compromise disputes"); Dattani v Trio Supermarkets Ltd [1998] EWCA Civ 158, [1998] ICR 872 (CA) at 874 per Mummery LJ ("'The law loves compromise.' So wrote Lord Bingham CJ in his foreword to the 4th edition (1996) of The Law and Practice of Compromise by David Foskett QC. The converse is also true. The law, in its promotion of finality and certainty in dispute resolution, loathes litigation about compromises."); Panayiotou v Sony Music Entertainment (UK) Ltd [1994] EMLR 229 (Ch) at 347 ("the public policy in favour of upholding compromises"); Barrett v Universal-Island Records Ltd [2006] EWHC 1009 (Ch), [2006] EMLR 21 at [166]: ("The whole point of a settlement is to bring finality."); and Re IMG Pension Plan [2010] EWCA Civ 1349, [2011] Pens LR 11 at [33]. 